\title{
Lumber Yield in a Portuguese Wooden Kitchen Furniture Industry
}

\author{
José Vicente Ferreira (Corresponding author) \\ Centro de Estudos em Educação, Tecnologia e Saúde, ESTGV, Instituto Politécnico de Viseu \\ Campus Politécnico de Repeses, 3504-510 Viseu, Portugal \\ E-mail: jvf@estv.ipv.pt \\ Carlos Ferrolho \\ Grupo Visabeira, Parque Industrial de Coimbrões, Viseu, Portugal \\ E-mail: carlosferrolho@visabeiraindustria.com \\ Idalina Domingos \\ Centro de Estudos em Educação, Tecnologia e Saúde, ESTGV, Instituto Politécnico de Viseu \\ Campus Politécnico de Repeses, 3504-510 Viseu, Portugal \\ E-mail: ijd@estv.ipv.pt
}

Received: June 18, 2011

Accepted: August 1, 2011

doi:10.5539/ibr.v4n4p24

\begin{abstract}
Wood industries are unquestionably important in the context of the Portuguese economy (14\% of industrial GDP), job creation $(260,000)$ and the settlement of people in poorer regions. The wood kitchen furniture industry is an important component of this sector.

Evaluating the wood kitchen furniture industry's level of efficiency is important to assist furniture companies in undergoing a rapid process of restructuring and modernization in response to competitive pressure, particularly international competition.

The objective of this research was to evaluate the lumber yield of a small scale Portuguese wood kitchen furniture industry in the central region of Portugal using an I/O (input/output) approach.

The results showed a lumber yield of $46 \%$ suggesting this company still operates below the average national sector yield (60.5\%) and confirming the potential to increase the firm's output (door frames) from existing inputs.
\end{abstract}

Keywords: Wood furniture industry, Kitchen furniture industry, Lumber yield

\section{Introduction}

The Portuguese furniture sector comprises around 2600 companies, generating a turnover of almost $€ 887$ million and employing around 30,000 people. In 2009 about $80 \%$ of production was exported which represented $20 \%$ of total exports of the sector dominated by micro enterprises ( $65 \%$ of furniture enterprises have fewer than 10 workers), but there are also some large manufacturers. The kitchen furniture subsector accounts for $12 \%$ of total furniture production value (AIMMP, 2009).

When compared with the European (EU27, 2006) furniture sector comprising around 150,000 companies, generating a turnover of almost $€ 126$ billion and employing around 1.4 million people we can conclude that the labour productivity (measured by gross value added per worker) in this sector in Portugal is just $€ 29,567$, i.e. less than half the average productivity of the domestic processing industry and about one third of the average $(€ 90,000)$ of European competitors.

A feature of this industry is that it is normally linked to low efficiency defined as the quantity of output $(Y)$ per unit of input $(\mathrm{X})$ used in the production process which is the average physical productivity (Olukosi, J.O. and P.O. Erhabor, 1998). Evaluating the wood furniture industry's level of efficiency in Malaysia (Alias Radam, et al. 2010) and in Nigeria (J.S. Alao and E.D. Kuje, 2010) the researchers concluded that the technical efficiency, using stochastic frontier production model, was $46 \%$ and $53 \%$ respectively.

The factors which affect the levels of inefficiency across industries reveals that about half the differences can be explained by: the extent of competition in the industry, the degree of product differentiation, the rate of structural 
change, the importance of international trade, the size of markets and the organization of firms within the industry (Alison Green and David Mayes, 1991).

According to Barbosa et al. (1999) low performance in most companies in the wood industry and furniture is due to precarious industrial organization and the cultural aspects of non-acceptance of innovation but in a study intended to analyze the relationship between productive efficiency and innovation in Spain's wood-based industry, the results did not show the existence of significant links between firm's efficiency and innovation (Luis Diaz-Balteiro et al. 2006).

The defects and abnormalities of wood and their technological consequences are important aspects that need attention since any irregularities or deviations in the wood diminishes its usability. A defect is by definition an irregularity occurring in or on wood that reduces its strength, durability, or usefulness (Willis Wagner and Clois Kicklighter, 2000). There is a certain amount of risk involved in classifying an abnormality (e.g. knot) as a defect because what is judged to be definitely unsuitable for one application may prove to be ideal for a different or special use (Kollmann/Côté, 1984). Some of the common defects include (Willis Wagner and Clois Kicklighter, 2000; Kollmann/Côté, 1984; NP-180, 1962; Irene Yu-Hua Gu, et al. 2010):

natural defects (knots, reaction wood, cross grain, variation in log form, shake, blue stain, miscellaneous natural defects);

defects due to processing:

manufacturing defects (slope of grain, wane, small dent, excessive variation in dimension);

seasoning defects (checks, warp, casehardening, collapse, honeycomb, wash boarding, miscellaneous seasoning defects (drying cracking, pitch pocket));

raised grain;

loosened grain.

The most common type of defect in wood machining processes is the slope of the grain which can be due to inaccuracy of the equipment or poor judgment and lack of skill on the part of the operators (Kollmann/Côté, 1984). To reduce the frequency of this type of defect it is necessary to increase the rake angles, thus decreasing the friction between the tools and chip surface and verifying the degree of rounding (radius) from the edge tools to avoid exceeding the permissible wear limit, so as to maintain the "wire" cutting (Koch P., 1964; Gonçalves M.T.T., 2000).

For wood furniture manufacturers, texture and the direction of the grain are the characteristics which most influence performance of the machining processes. The silica and gum content are also characteristics that affect the quality and productivity of the manufacturing processes (Silva, J. et al.,1999).

According to Lyptus, (2002), the problems arising from variations in grain, color, surface cracks, warping lights and contractions may be corrected or minimized through appropriate processing techniques - drying, machining and finishing.

The production of wooden kitchen furniture requires the removal of defects (also called unacceptable character marks) from boards used as raw-material. Today, the majority of the wood processing industry uses human resources to identify such defects and to mark them with fluorescent markers (Urs Buehlmann and R. Edward Thomas, 2007). According to these authors a study found that yield losses incurred due to inaccurate marking are over 15 percent absolute lumber yield and large yield improvements can be achieved if marker accuracy is improved only marginally. Average yield from primary parts after rejecting was found to be 39.1, 44.4, and 45.7 percent for the normal error rate; 25 percent error reduction; and 50 percent error reduction scenario, respectively.

A study (field test of the RIP-X crosscut-first and rip-first simulation) of rough mill cutup of 4/4 red oak lumber was conducted in a casegoods manufacturing company by O. V. Harding and P. H. Steele, (1997). For the crosscut-first system the study was conducted over three days and the overall rough mill yield was $54.46 \%, 57.21 \%$ and $61.63 \%$ for day 1, 2 and 3 respectively. For the rip-first system the rough mill was studied for one-half day and the overall rough mill yield was $71.26 \%$.

According to a study carried out by INETI (2000) the overall rough Portuguese furniture sector yield was $60.5 \%$ in 1998 which is in accordance with the results above.

Damavan et al. cited by J.S. Alao and E.D. Kuje, (2010) posited that many small scale enterprises lack the necessary skills and resources to operate efficiently and are ill prepared to deal with the problem of production and the severe constraints they face in their management skills. 
Performance improvement can be grouped into production improvement, in preventing and recovering failure and in quality management. The widely techniques for performance improvement, are according Slack Nigel et al., (1997): I/O (input / output) analysis, failure mode and effect analysis (FMEA), letters of statistical process control, flow charts, relationships diagrams, cause-effect diagrams.

This paper attempts to evaluate the lumber yield of a small scale Portuguese wooden kitchen furniture industry in the central region of Portugal using an I/O (input/output) approach.

\section{Case Study}

The wooden kitchen furniture manufacturing company whose lumber yield we intended to study is a small scale enterprise (SSE), which uses the best available technology. It is located in the central region of Portugal. The kitchen manufacturing process is divided into two production lines: "lumber line" and "box line". In the "lumber line" framed panels (panel doors and/or panel drawers) are produced in accordance with the flow chart represented in Fig. 1 and the woodworking machines involved are: "multi-saw", "moulder", "radial saw", "tenoner", "mortiser", "press" and "sander".

The lumber used 2.24 cubic meters $\left(\mathrm{m}^{3}\right)$ of oak lumber $\left(650 \mathrm{~kg} / \mathrm{m}^{3}\right.$ density with $10 \%$ humidity) with length (3650 $\mathrm{mm})$, thickness $(26 \mathrm{~mm})$ and varying width $(110-320 \mathrm{~mm})$ to produce $1.02 \mathrm{~m}^{3}$ of frames. The lumber was "ripped" (cutting along the length) into strips (75 mm wide) with a "multi-saw" using saw blades ( $3 \mathrm{~mm}$ thick). After being processed by the "moulder" machine the size of the strips was $(3650 \times 70 \times 23 \mathrm{~mm})$. With the "radial saw" the strips were "chopped" into shorter pieces to take out the defects (knots, cracks, etc.) and then cut lengthwise to obtain rails and stiles. A tenon was inserted into the rails with the "tenoner" machine. A rectangular hole was cut into the stiles to accept a tenon with a "mortiser" machine. The "press" machine was used to assemble the panel doors and panel drawers. The panels were not included in the study, because they were made from another material out of this production line. Finally, the panel doors and panel drawers passed through the "sander" to reach its final thickness $(22 \mathrm{~mm})$ and a surface ready for finishing. Table 1 gives the stiles and rails manufactured for this study.

\section{Methodology}

A mass balance was performed across the "lumber line" using the I/O (input/output) technique (Slack Nigel et al., 1997) to evaluate the yield of each unit process (woodworking machine) and of the overall "lumber line".

The quality assessment of the machined wood was performed according to Portuguese Standard NP-180 which defines the most important causes of wood devaluation.

\section{Results and interpretation}

As shown in Fig. 2, the lumber yield in this enterprise is only $46 \%$ which means that more than half (54\%) of the raw material is converted into solid waste and is not incorporated into the final product. This result contrasts with the $(60.5 \%)$ for the overall rough Portuguese furniture sector yield [INETI, 2000] but it is of the same magnitude as the (45.7\%) in the Urs Buehlmann and R. Edward Thomas (2007) study and (54.46\%) in the O. V. Harding and P. H. Steele, (1997) study.

The unit processes yield (woodworking machines) included in the "lumber line" is represented in Figure 3. As expected, the "moulder" operation is one that presented a lower yield $(76 \%)$ because this is the operation where the major irregularities of raw material were corrected. Rather than this] the higher efficiency $(99 \%)$ was obtained in the "mortise" machine followed by the "sander" and the "tenoner" machine with 95\% each. The efficiency (83\%) obtained in the "radial" machine was influenced mainly by the wood defects. The width of the board was the main issue responsible for the yield ( $80 \%$ ) on the "multi-saw" machine. In this unit operation board width (a multiple of $80 \mathrm{~mm}$ ) presented a higher yield (94\%), whereas $150 \mathrm{~mm}$ wide boards presented a lower yield (50\%).

The distribution of wood machining defects that contributed to yield reduction is presented in Fig.4. The "raised grain" and "slop of grain" accounted for approximately $2 / 3$ of the total machining defects $(32 \%$ each), and $14 \%$ of defects were due to "wane". "Small dent" and "loosened grain" accounted for the lowest number of defects (11\% each).

The distribution of natural and seasoning wood defects that contributed to yield reduction is presented in Fig.5. "Blue stain" (24\%), the defect which appeared most often, together with "mineral streak" (21\%) and "warping" (18\%) accounted for approximately $2 / 3$ of the total defects. "Knots" and "splits/check/shake" accounted equally (15\% each) for $30 \%$ of the total defects. "Pitch pocket" was the defect that appeared the least (6\%).

\section{Conclusions}

The main conclusion to be drawn from this study is that the company needs $2.24 \mathrm{~m}^{3}$ of oak wood (raw-material) to produce $1.02 \mathrm{~m}^{3}$ of frames to panel doors and panel drawers for kitchen furniture. This makes the yield only $46 \%$, 
which contrasts with the average value of $60.5 \%$ for the national wood furniture sector. Nevertheless, it is of the same magnitude (45.7\%) found by Urs Buehlmann and R. Edward Thomas (2007) and a little different of 54.46\% found by O. V. Harding and P. H. Steele, (1997) in similar studies.

The unit process that had the lowest yield (76\%) was in the "moulder" machine followed by the "multi-saw" $(80 \%)$ and the "radial" machine (83\%). The yield on the multi-saw was influenced mainly by the width of the board lumber feed, ranging from $94 \%$ (for board widths which were multiples of $80 \mathrm{~mm}$ ) to $50 \%$ (for board widths of $150 \mathrm{~mm}$ ). The defects of the wood and machining were the variables that contributed most to the yield of the operation in the "radial" machine. The unit process in the "mortiser" machine is one that presents the greatest mass yield (99\%), followed by the "sander" and "tenoner" at $95 \%$ each.

Approximately $2 / 3$ of the total machining defects are due to the "raised grain" and "slope of grain" (32\% each).

"Blue stain" (24\%), "mineral streak" (21\%) and "warping" (18\%) accounted for approximately $2 / 3$ of the total natural and seasoning wood defects. "Knots" and "splits/check/shake" accounted equally ( $15 \%$ each) for $30 \%$ of the total defects and "pitch pocket" was the defect appeared the least (6\%).

\section{References}

AIMMP. (2009). A fileira da madeira e mobiliário em Portugal - Caracterização estatística. Associação das Indústrias de Madeira e Mobiliário de Portugal (AIMMP). [Online] Available at: http://www.aimmp.pt/DOCUMENTOS/dados-sectoriais-2009.pdf (March 6, 2011)

Alias Radam, Mohd Rusli Yacob, Huda Farhana Mohd Muslim. (2010). Technical Efficiency of the Malaysian Wooden Furniture Industry: A Stochastic Frontier Production Approach. International Business Research, Vol. 3, No. 3.

Alison Green and David Mayes, (1991). Technical Inefficiency in Manufacturing Industries. The Economic Journal, 101, 523-538, doi:10.2307/2233557, http://dx.doi.org/10.2307/2233557

Barbosa, Ana Paula; Vianez, B.F.; Varejão, M. J.; Abreu, R.L.S. (1999). Considerações sobre o perfil tecnológico do setor madeireiro na Amazônia central. Revista Acta Amazônica. Biodiversidade, pesquisa e desenvolvimento na Amazônia. Manaus, n.35, p 45-53.

EU 27. (2006). The furniture industry sector. European Commission. [Online] Available at: http://ec.europa.eu/enterprise/sectors/furniture/index_en.htm (March 8, 2011)

Gonçalves M.T.T. (2000). Processamento da Madeira. Bauru-SP: Document Center Xerox -USC, Livro ISBN 85.901425-1-5.

INET. (2000). Guia Técnico - Sector da Industria da Madeira e Mobiliário. Instituto Nacional de Engenharia e Tecnologia Industrial, Lisboa.

Irene Yu-Hua Gu, Henrik Andersson, Raul Vicen. (2010). Wood defect classification based on image analysis and support vector machines. Wood Science and Technology 44, 693-704, doi:10.1007/s00226-009-0287-9, http://dx.doi.org/10.1007/s00226-009-0287-9 .

J.S. Alao and E.D. Kuje. (2010). Determination of Technical Efficiency and Production Function for Small Scale Furniture Industry in Lafia Metropolis, Nasarawa State, Nigeria. Journal of Agriculture \& Social Sciences. ISSN Online: 1814-960X, 09-037/AWB/2010/6-3-64-66. Available at: http://www.fspublishers.org/jass/past-issues/JASSVOL_6_NO_3/6.pdf (March 3, 2011)

Koch P. (1964). Wood Machining Processes. New York. Ronald Press Company. 1964. 530p.

Kollmann/Côté. (1984). Principles of Wood Science and Technology. Vol I: Solid Wood. Springer-Verlag, Berlim Heidelberg New York Tokyo.

Luis Diaz-Balteiro A. Casimiro Herruzo, Margarita Martinez and Jacinto González-Pachón. (2006). An analysis of productive efficiency and innovation activity using DEA: An application to Forest Policy and Economics, Volume 8, Issue 7 October 2006, Pages 762-773

Lyptus. (2002). Recomendações técnicas de usinagem, colagem e acabamento. 17p (folder).

NP-180. (1962). Anomalias e defeitos da madeira. Norma Portuguesa NP-180, Instituto Português da Qualidade (IPQ).

Olukosi, J.O. and P.O. Erhabor. (1998). Introduction to Farm Management Economics: Principles and Applications, pp:35-80. Agitab Publishers, Zaria. 
O. V. Harding, P. H. Steele. (1997). RIP-X: Decision software to compare crosscut-first and rip-first rough mill. Wood Science and Technology 31, 367-381 (C) Springer-Verlag 1997, doi:10.1007/s002260050043, http://dx.doi.org/10.1007/s002260050043

Silva, J., Mattos, J; Muniz, G.B. (1999). Influência das características anatômicas da madeira na sua usinagem. XV Congresso florestal brasileiro. Belo Horizonte. Anais, p232- 239.

Slack, Nigel et al. (1997). Administração da Produção. São Paulo. Atlas.

Urs Buehlmann, R. Edward Thomas (2007). Relationship between lumber yield and board marker accuracy in rip-first rough mills. Holzals Roh- und Werkstoff 65, 43-48, doi:10.1007/s00107-006-0099-7, http://dx.doi.org/10.1007/s00107-006-0099-7

Willis Wagner and Clois Kicklighter. (2000). Modern woodworking: tools, materials, and processes. Copyright 2000 by The Goodheart-willcox Company, Inc., USA.

Table 1. Stiles and rails manufactured

\begin{tabular}{lll}
\hline Parts & Length $\times$ Width $\times$ Thickness $(\mathrm{mm})$ & Number \\
\hline \multirow{4}{*}{ Stiles } & $243 \times 70 \times 22$ & 4 \\
& $293 \times 70 \times 22$ & 120 \\
& $343 \times 70 \times 22$ & 68 \\
& $393 \times 70 \times 22$ & 166 \\
& $493 \times 70 \times 22$ & 166 \\
\hline \multirow{4}{*}{ Rails } & $693 \times 70 \times 22$ & 2 \\
& $138 \times 70 \times 22$ & 72 \\
& $278 \times 70 \times 22$ & 36 \\
& $560 \times 70 \times 22$ & 30 \\
& $700 \times 70 \times 22$ & 312 \\
& $900 \times 70 \times 22$ & 24 \\
& $1308 \times 70 \times 22$ & 28 \\
\hline
\end{tabular}

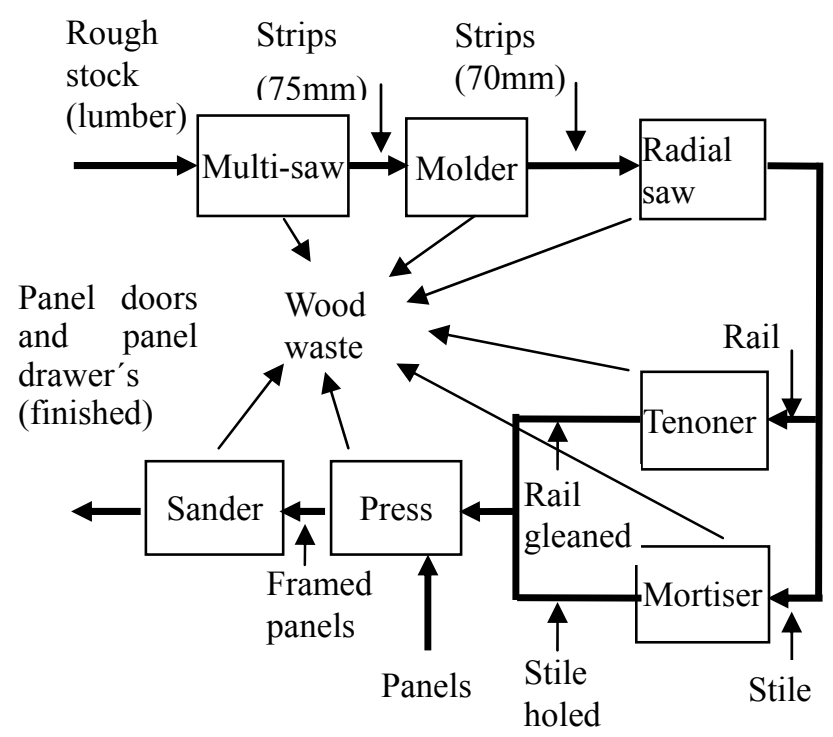

Figure 1. Flow chart of "lumber line" 


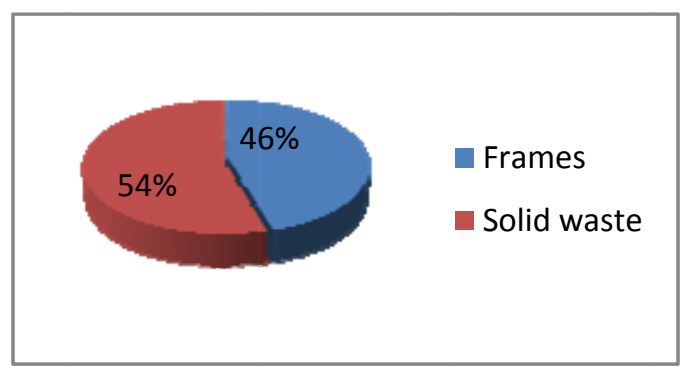

Figure 2. Lumber yield

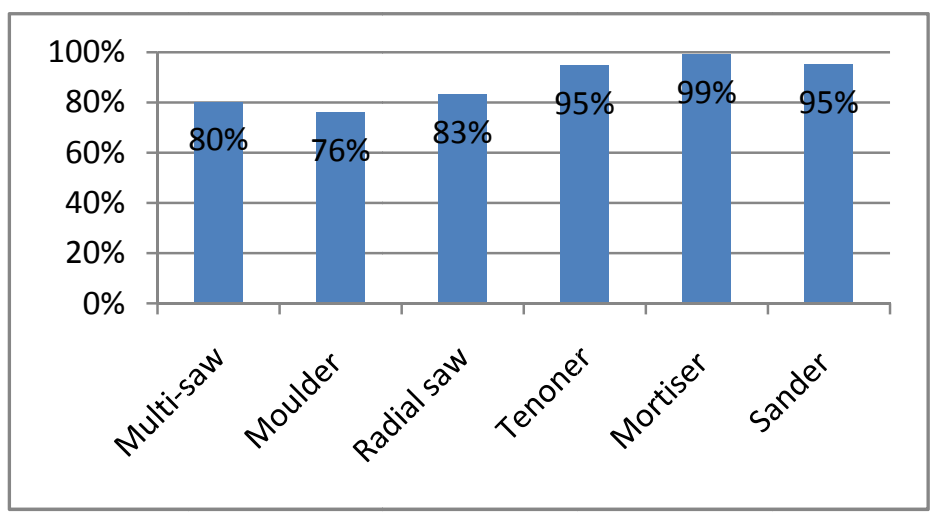

Figure 3. Unit processes yield

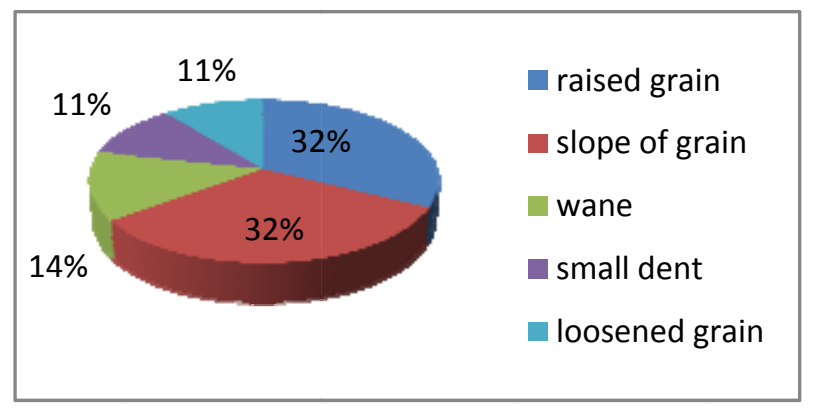

Figure 4. Distribution of wood machining defects

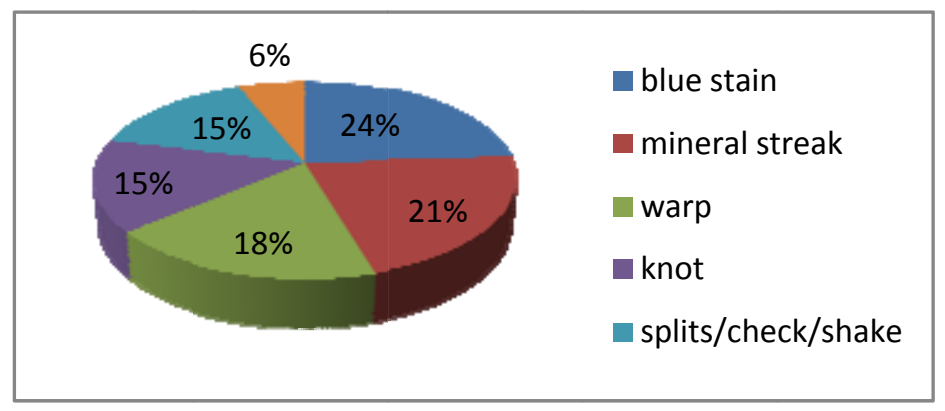

Figure 5. Distribution of natural or seasoning wood defects 